\title{
Who pays attention to the moral aspects? Role of organizational justice and moral attentiveness in leveraging ethical behavior
}

\author{
Hussam Al Halbusi \\ Department of Management, \\ Ahmed bin Mohammed Military College, Doha, Qatar
}

\begin{abstract}
Purpose - Although there have been several studies on corporate justice and employee ethical behavior, little is known about the conditions in which this link develops. The purpose of this study is to investigate the direct effect of organizational justice and moral attentiveness toward employee ethical behavior. Importantly, this study also considers the moderating role of moral attentiveness on the links between organizational justice and employee ethical behavior.

Design/methodology/approach - The data was collected from 350 employees who were assessed directly to supervisors in 12 manufacturing companies placed in Malaysia, operated full-time, and had regular interaction with their direct supervisors. In particular, using two-wave survey data obtained from 270 employees working in the manufacturing industry in Malaysia.
\end{abstract}

Findings - Results showed that organizational justice and moral attentiveness positively impact the employee ethical behavior as predicted. New to the literature, findings disclose that moral attentiveness strengthens this relationship. Importantly, the positive impact of organizational justice is sharply positive under high than low moral attentive employees and ceases to be significant among low morally attentive personnel.

Research limitations/implications - This research focused on the notion of ethics and how important it is for society. The principles, norms and ideals that guide an individual's behavior are referred to as ethics. Because the authors need to be treated with dignity as human beings, ethical behavior is essential in society.

Practical implications - The findings of this study send a clear signal to managers that "failing to ensure that their employees perceive organizational justice" may undermine every effort made by them to improve their organizations' ethical quality. Importantly, the findings emphasize the role of moral attentiveness in improving the ethical behavior of employees both directly and by strengthening the effectiveness of organizational justice to impact such a behavior positively. So, given the advantages of moral attentiveness in terms of improving employee ethical conduct, businesses should make every effort to hire and choose people who meet this requirement because it is not easy to spot this personality trait. Human resource managers may assess candidates' moral attentiveness using a range of methods such as group debate, an in-basket exercise, organized interviews and business games that concentrate on specific ethical concerns.

Social implications - This research focused on the notion of ethics and how important it is for society. The principles, norms and ideals that guide an individual's behavior are referred to as ethics. Because the authors need to be treated with dignity as human beings, ethical behavior is essential in society.

Ethical approval: Researchers conduct studies involving human participants per institutional and national research committee's ethical standards and the 1964 Helsinki declaration and its later amendments or comparable ethical standards.

The author would like to thank the action editor Sebastian Berger and the anonymous reviewers for their very helpful and constructive comments and guidance on earlier versions of this manuscript.

Informed consent: I obtained informed consent from participants.

Funding: There was no funding for this research project.

Conflict of Interest: I declared no conflict of interest.

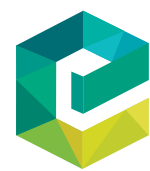

International Journal of Ethics and 
Originality/value - The results of this study demonstrate how the eye is put to attain organizational moral excellence; the outcomes have shown that acutely attentive employees to the moral cues offered by the organization is vital.

Keywords Organizational justice, Employee ethical behavior, Moral attentiveness, Moral issues

Paper type Research paper

\section{Introduction}

Recent ethical scandals (i.e. Deutsche Bank, the London Interbank Offered Rate, Volkswagen) have led to accusations that businesses are engaging in unethical practices have piqued people's interest in learning more about the causes of such moral failure (A1 Halbusi and Tehseen, 2017; Al Halbusi et al., 2020a). Because the behavior of all the members of the organization is the principal indicator of the ethical quality of an organization, one of these sources has to do with all those factors, both internal and external, which can lead to employees to develop unethical behaviors in the workplace. Hence, employee ethical conduct can be influenced by a variety of factors, which must be observed and defined to prevent problems (Mitchell et al., 2017; Wiernik et al., 2018; Al Halbusi et al., 2020b). Among this fairness is one of the most significant factors influencing workers' right behaviors is their views of the fairness that exists in their workplaces (Ambrose and Schminke, 2009; Colquitt et al., 2001; Karam et al., 2019). Because justice is profoundly entrenched in every individual's ethical assumption (Moardi et al., 2016; Rounaghi, 2019; Pratono, 2019), it is no surprise that organizational justice, defined as employees' perceptions of distributive, procedural, interpersonal treatment and informational fairness in the organization (O'Keefe et al., 2019), becomes a fundamental virtue and a principal ethical concern of employees concerning what they seek to fulfill from and in their organizations (Treviño et al., 2014). Nevertheless, despite present works signifying a positive association among organizational justice and employee ethical conduct (Shah et al., 2017; Ko et al., 2018; Al Halbusi et al., 2017; Al Halbusi et al., 2019), yet there are inconclusive results on this relationship (Cho and Tak, 2009). Hence, further research is needed to uncover which potential variables could be masking this relationship.

One person-related variable that could play a significant role in this association is moral attentiveness. In fact, the latest evidence into the cognitive processing of moral cues indicates that employees' levels of exposure to ethical issues vary (Hannah et al., 2011; Reynolds and Ceranic, 2009; Zhu et al., 2016), and these variances are taken by moral attentiveness, the degree to which an individual chronically observes and considers morality and moral essentials in his or her experiences (Reynolds, 2008). With a higher level of moral attentiveness, individuals can pay more attention to ethics, internalize ethical prototypes about how to solve ethical dilemmas and perform in terms of ethics far better (Wurthmann, 2013; Sturm, 2018). Besides, with higher moral attentiveness, the sensitivity of members to moral signals improves, thus given that the core aspect of organizational justice is the fairness of moral cues, the relations between organizational justice on employee ethical behavior may be conditional on this trait (i.e. moral attentiveness). The primary research goal is thus to expound on the role of organizational justice in the positive association between organizational justice and employee moral behavior and how moral attentiveness can help explicate this relationship. To this end, this study initially inspects the positive effects of organizational justice (organizational variable) and moral attentiveness (individual variable) on employee ethical behavior. Then, explore the moderating (strengthening) role of moral attentiveness in the organizational justice-employee ethical behavior relationship and 
thus shed light on "when" organizational justice is most effective in impacting employee ethical behavior positively.

All these efforts advance prior research by adding to the scarce literature concerning the positive role of moral attentiveness in explaining employee ethical behavior. Although previous research has found a positive association of this trait with aspects intimately related to ethical decision-making (i.e. moral awareness, Reynolds, 2008; moral imagination, Whitaker and Godwin, 2013), other studies fail to do so or ignore the analysis of this direct relationship (i.e. van Gils et al., 2015). The current study is one of the few that tests this relationship directly to help shed light on this relationship. More importantly, the current study represents an important contribution to social cognitive theory (Bandura, 1986; Fiske and Taylor, 1991; Fiske, 1993) in which the concept of moral attentiveness is rooted upon (Reynolds, 2008) and to the existing organizational-individual interactionist perspective to explain how ethical behavior is developed in organizations or other social contexts (Treviño, 1986; Treviño et al., 2006; O'Keefe et al., 2019). While social cognitive theory understands that behavior is a function of individuals, the stimuli received and the interaction of two (Bandura, 1986), the organizational-individual interactionist perspective (i.e. Treviño, 1986) assumes that ethical behavior is explained by the interaction of both these types of variables. With this study, this study contributes to both theories by identifying the boundary conditions on which the organizational justice-employee ethical behavior rests upon. Furthermore, this study responds to previous calls to investigate the potential moderating role of moral attentiveness in accounting for ethical behavior in organizations (Zhu et al., 2016). To my knowledge, only van Gils et al. (2015) studied this role of moral attentiveness, and they did it in the relationship between unethical supervision (at the group level) and deviant behavior by finding that moral attentiveness could make employees respond to unethical supervisors with a stronger unethical behavior. This investigation is different from that of van Gils et al.'s (2015) in that it evaluates how a different level constructs, an organizational construct such as organizational justice, impacts the ethical behavior of high versus low morally attentive employees, which would help add evidence on the predictable strengthening role of moral attentiveness in explaining the impact of the context on employee ethical behavior. This study will thus indicate to general managers "when" their efforts to make that justice is perceived in the outcomes, procedures, interpersonal treatment and information received within the organization (i.e. organizational justice) can help most to enhance ethical behavior in the workplace. It would allow offering critical cues to managers on "when" to better leverage their efforts to gain a reputation of a just or fair organization, and thus help these managers to gain compelling insights on the specific actions that they can take (i.e. to gain or have a highly morally attentive workforce) to ensure that organizational justice can enhance their organizations' ethical quality, from top to down.

\section{Theoretical background and hypotheses development}

\subsection{Organizational justice and employee ethical behavior}

Individuals are genuinely concerned about how they are treated and how justice is reflected in their workplace's procedures, achievements, personal experiences and knowledge. Fairness and justice attitudes in the workplace (Cropanzano and Greenberg, 1997; Greenberg, 1990; O'Keefe et al., 2019), organizational justice encompasses four key components: distributive, procedural, interpersonal and informational (Colquitt, 2001). The first component is distributive justice, which is related to Adams's (1963) equity theory and addresses the equitable allocation of consequences depending on each individual employee's performance (Burney et al., 2009; Steensma and Visser, 2007; Salehi et al., 2020a, 2020b). 
Another component is procedural justice, which pertains to the perceived fairness of the methods, procedures and policies that are used to determine outcomes or resource allocations (Ambrose and Schminke, 2009; Colquitt, 2001; Greenberg, 2001). When it comes to organizational justice, interpersonal treatment is equally crucial; this component emphasizes the quality of treatment (i.e. respectful, with dignity) received in interpersonal interactions with others, particularly with supervisors (Bies and Moag, 1986). Finally, informational justice is an element of organizational justice that relates to whether important information is received in a timely, accurate and unbiased way (Colquitt, 2001).

With the perception of organizational justice, the ethical behavior of employees can be positively impacted. In effect, all these components have a positive impact on the behavior of employees, principally by triggering social exchange processes associated with social exchange theory (SET) (Blau, 1964; Gouldner, 1960). For instance, when distributive and procedural justice is apparent, the settings at work should be perceived as further encouraging distributive justice (Oshio and Kobayashi, 2009), with employees also perceiving that they have some voice in making decisions procedural justice (Lind and Tyler, 1988). Therefore, drawn on SET, reciprocity could be derived (Blau, 1964; Gouldner, 1960) and lead employees to respond with positive behaviors to the organization, such as ethical behavior (Shah et al., 2017; McCain et al., 2010). The same holds true for interpersonal justice and informational justice. When employees perceive that leader treats them fairly (interpersonal justice) and that they receive accurate and honest information concerning the idiosyncrasies of the organization (informational justice), they are likely to believe that their employer and leader appreciate and respect them as persons, and a social exchange processes scenario is likely to emerge. Employees in such a situation are more likely to trust their bosses and hence feel obligated to repay them (Colquitt et al., 2007), with behaviors that benefit the company as well, making them less inclined to act unethically (Mayer et al., 2009).

General, organizational justice includes important ingredients of ethical behavior (Lind, 2001), and whether it is perceived by employees, ethical behavior will be favored, as a feeling of obligation to reciprocate with such a behavior is likely to be developed among employees (El Akremi et al, 2010). Employees need that procedures, information, treatment and outcomes within the organization become known and rooted upon justice; it is, in fact, a vital element for employees' well-being (Lin et al., 2009; Roch et al., 2019). Being just shows the organization's integrity to its employees, who are more likely to be fostered in the belief that ethics is a critical compass in their work. Otherwise, they are likely to be skeptical about their organization's actual interest and concern for their needs as individuals, and may likely act immorally to achieve their own goals due to perceived injustice and a lack of moral principles in their organization (Demirtas, 2015; Karam et al., 2019; Al Halbusi et al, 2021a), it is unlikely that the workforce will trust the relationship with their organization if they find out that procedures, outcomes, interpersonal treatment and information displayed in the organization are not adhered to justice principles. Thus, based on the above argumentations, they postulate that organizational justice is a positive for employee ethical behavior. Employees operating in equal settings are more willing to assume that organizational fairness is true, making social exchange processes easier (Colquitt et al., 2007; Al Halbusi et al., 2021b), leading employees to involve in positive actions such as ethical behavior (Ko et al., 2018). Thus, we theorized as follows:

H1. Perceived organizational justice is positively related to employee ethical behavior.

\subsection{Moral attentiveness and employee ethical behavior}

Individuals' ethical behavior can be influenced by person-related aspects in the situation (Craft, 2013). Moral attention, which Reynolds coined based on social cognitive theory 
(Bandura, 1986) as the amount to which morality is perceived in day-to-day situations, is one individual difference that could have anything to do with ethical behavior (Reynolds, 2008).

Moral attentiveness is a relatively recent idea in the ethics literature (Reynolds, 2008; Wurthmann, 2013), and it has gotten a lot of attention from academics in the previous 10 years (van Gils et al., 2015; Zhu et al., 2016; Dawson, 2018). Moral attentiveness, in its two important basic aspects (perceptual and reflective), is likely to have a favorable impact on ethical behavior because it causes people to reason about and perceive morality on a regular basis (Reynolds, 2008; Wurthmann, 2013). In effect, the possession of this trait makes individuals interpret information that they have through an ethical lens (i.e. perceptual moral attentiveness) and reflect back on their experiences from an ethical outlook prior to making decisions (i.e. reflective moral attentiveness, Reynolds, 2008), so it is no surprise that these individuals become more prone to make good ethical decisions. Previous research has found a strong link between this feature and characteristics that are closely related to ethical decision-making. Moral attention, for instance, has been linked to moral imagination, and hence to the ability to contemplate and evaluate new options in terms of moral worth and positive ethical impact (Whitaker and Godwin, 2013). Also, moral attentiveness has been observed to be positively related to the perception that ethics and social responsibility are outstanding to be effective in business (Wurthmann, 2013), which Dawson (2018) claims as a necessary condition for an individual to behave ethically. In addition, moral attentiveness is said to be closely related to moral awareness, that is, the ability of an individual to recognize that a situation encompasses moral content and requires from an ethical-lens based evaluation (Reynolds, 2006), which is critical to make ethical decisions (van Gils et al., 2015). Finally, recent research has also displayed how moral attentiveness could be positively related to having ethical prototypes about different ethical issues (e.g. lying, deceiving, cheating) internalized in their minds, and therefore normative evaluations (i.e. the extent to which the issue in question is in line with moral standards) and prescriptive recommendations (i.e. how to act and react to this issue), which would help to promote the making of ethical decisions (Sturm, 2018). Overall, as shown by the preceding rationales and evidence, moral attentiveness could be positively related to ethical behavior. While perceptual moral attentiveness is linked to higher moral imagination and the possession of ethical prototypes on how to act on ethical dilemmas, reflective moral attentiveness is positively associated with perceptions that ethics is important in business and also with higher moral awareness levels (Sturm, 2018; Al Halbusi et al., 2021a). Thus, we hypothesized accordingly:

H2. Moral attentiveness is positively related to employee ethical behavior.

\subsection{The pivotal role of moral attentiveness}

To understand how ethical behavior evolves, a prominent research line in the literature involves an interaction of individual characteristics with the environment or context (Treviño, 1986; O'Keefe et al., 2019). In this sense, Reynolds (2008), drawn on the social cognitive theory (Bandura, 1986; Fiske, 1993), suggests that ethical behavior could be caused by the interaction of some person-related factors with other contextual factors that offer external stimuli. Thus, given that moral attentiveness refers to the extent to which one pays attention to moral cues of the close context (van Gils et al., 2015; Al Halbusi et al., 2021a), this trait could interact with organizational justice perceptions to explain employee ethical behavior. While the possession of this trait could make individuals become more likely to pay attention to the existing immediate moral cues, its absence would lead individuals to become indifferent to the moral cues that the context releases. Therefore, the extent to which
Leveraging ethical behavior 
individuals are more or less morally attentive could be a potential explanation of the different ways a person reacts to the context (van Gils et al., 2015; Ko et al., 2018), or as it is the case in this study, to the perceived fairness in the procedures executed and the outcomes, interpersonal treatment and information received by employees within the organization.

Given that people's behavior is always filtered by their cognitive schemas and the processes through which they perceive their environmental conditions (Whitaker and Godwin, 2013), the higher the level of moral attentiveness possessed, the greater the employees' curiosity about moral issues and the greater the vividness and salience of these issues to these individuals' eyes and minds. Hence, given the higher agility with which high morally attentive employees can encode moral information (Bargh and Thein, 1985), in an automatic manner (Bargh, 1989), situational cues, such as those available as a consequence of perceived organizational justice, should enhance the ethical behavior of these individuals (Giessner and van Quaquebeke, 2010; Ko et al., 2018). High morally attentive employees are more likely than low morally attentive employees to have a stronger preference for ethicsbased concerns such as justice (Reynolds, 2008). As a result, organizational justice's positive impact on employee ethical behavior is more likely to be stronger in high morally attentive employees than in low morally attentive employees. On the contrary, given the low morally attentive employees' predicted lack of sensitivity to moral cues, the fact that organizational fairness is seen in their organization could become sterile in explaining and predicting these employees' ethical behavior. So, the following hypothesis was suggested:

H3. The positive relationship between perceived organizational justice and employee ethical behavior is stronger for followers who are high rather than low in moral attentiveness.

In essence, all the above-mentioned three hypotheses together help build a theoretical perspective that explains the occurrence of ethical behavior in the workplace. Figure 1 shows the research model to be tested in this study.

\section{Methodology}

\subsection{Participants and procedure}

The data was collected from 350 employees who assessed directly to supervisors in 12 manufacturing companies placed in Malaysia, operated full-time and had regular interaction with their direct supervisors. To reduce the likelihood of common method variance (CMV), the surveys were distributed in two-waves of as recommended (Podsakoff $e t$ al., 2013, 2012). In the first wave, participants filled their demographic details and their organizational

Figure 1.

Research framework

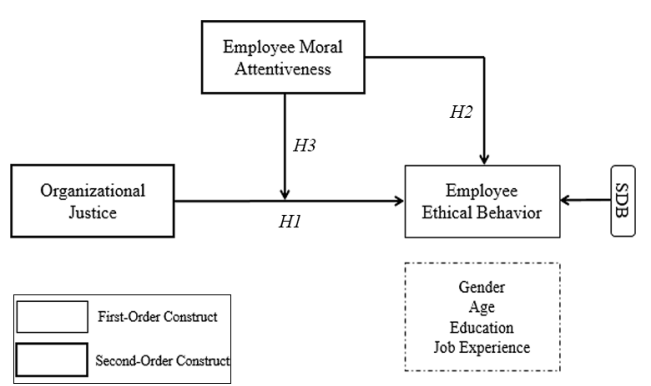

Note: $\mathrm{SDB}=$ social desirability bias 
fairness perceptions. In the second wave, later three weeks had passed, these respondents assessed their level of moral attentiveness and ethical conduct. A cover letter was also given to the respondents, who were ensured of full confidentiality and told of the importance of their participation in this research, which may help minimize the social desirability bias (SDB) and CMV (Podsakoff et al., 2013, 2012). The responses on both sets of surveys were coded to ensure that they could be linked; overall, 270 valid responses were received, with a response rate of $77 \%$. As found that $74.4 \%$ of the respondents were men and $25.6 \%$ women, with the biggest number $(41.9 \%)$ falling between the ages of 31 and 40 . In terms of educational achievement and work experience, the majority of participants (55.9\%) had a bachelor's degree and had worked in the same business for 6-10 years (75\%).

\subsection{Measurement of the variables}

Prior to distributing the survey to the respondents, the survey was checked with six experts in the field of ethics and justice; the survey questions were also checked and validated through cognitive interviews with 18 manufacturing industry workers, who recommended minor changes and validated the questionnaire's clarification, readability, comprehension and appropriateness. The questionnaires were provided to workers with at least six months of experience in their organizations to obtain credible answers. All these processes were before and after using Brislin's (1980) process for translating survey objects into Malayan and confirming semantic equivalence with their English counterparts. Nevertheless, the nature of the variables for this study enabled led to differentiate first- (i.e. employee ethical behavior, SDB) and second-order constructs (i.e. organizational justice, employee moral attentiveness), captured in Mode A (reflective) constructs, as recommended (Hair et al., 2017; Sarstedt et al., 2019). Thus, all measures relied on five-point Likert response formats, and except organizational justice ( $1=$ to a small extent" to " $5=$ to a large extent), all were based on the respondent's level of agreement on each item $(1=$ strongly disagree; $5=$ strongly agree). Table 1 shows the items of the main study variables.

3.2.1 Organizational justice. This variable was measured using 20 items from Colquitt's (2001) scale, which refer to "distributive justice," "procedural justice," "interpersonal justice" and "informational justice." Distributive Justice was measured using four items which concentrate on equal payment, promotion, sufficient recognition and rewards. A sample item is "Does your outcome reflect the effort you have put into your work?". For Procedural Justice, seven-items were used, all of which are intended to determine the degree to which policies and standards are followed fairly and uniformly across the company. Three-items showed poor loadings (far lower than 0.40, Hair et al., 2017), so they were dropped. Interpersonal Justice was assessed using a four-item scale concerning employees' interaction with their manager and whether or not their manager treats them with respect and politeness. Finally, for informational justice, five-items have been used to assess how well the authority figure followed the policies in relation to the information given. With all these four scales, a Mode A second-order composite (hierarchical common factor) was built, where all justice components represent lower-order constructs that are reflectively measured (Becker et al., 2012).

3.2.2 Employee moral attentiveness. This variable was measured using Reynolds's (2008) 12 -item scale, which includes both perceptual (7 items) and reflective (5 items) dimensions. The perceptual dimension refers to screening incoming information according to a moral perspective; the reflective dimension refers to using morality to consider and reflect on information (Reynolds, 2008). In one slight change to Reynolds's (2008) scale, items reworded a negatively framed item ("I rarely face ethical dilemmas") to make it positive ("I always face ethical dilemmas"), as recommended in the pre-test. Both dimensions combined 


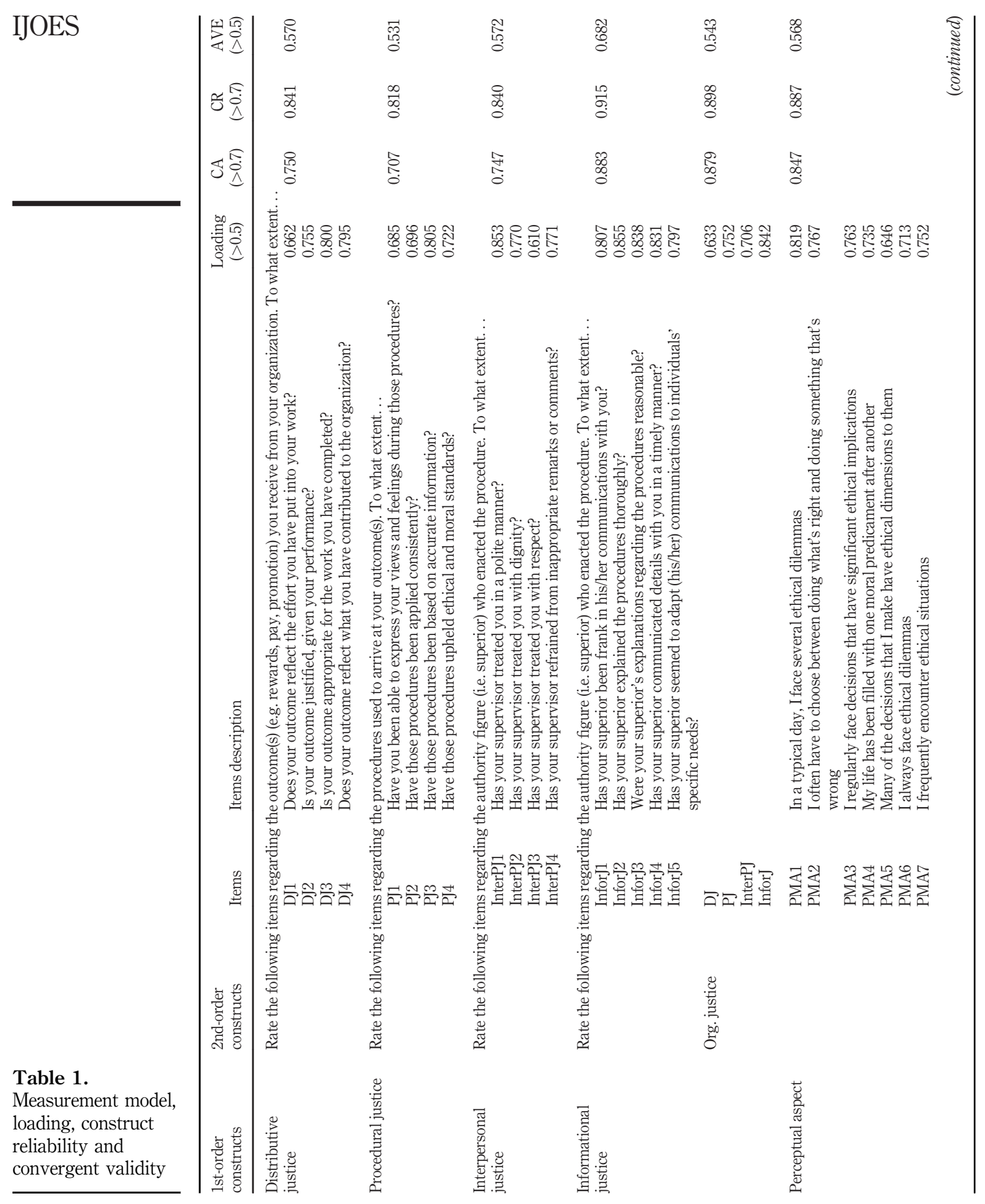




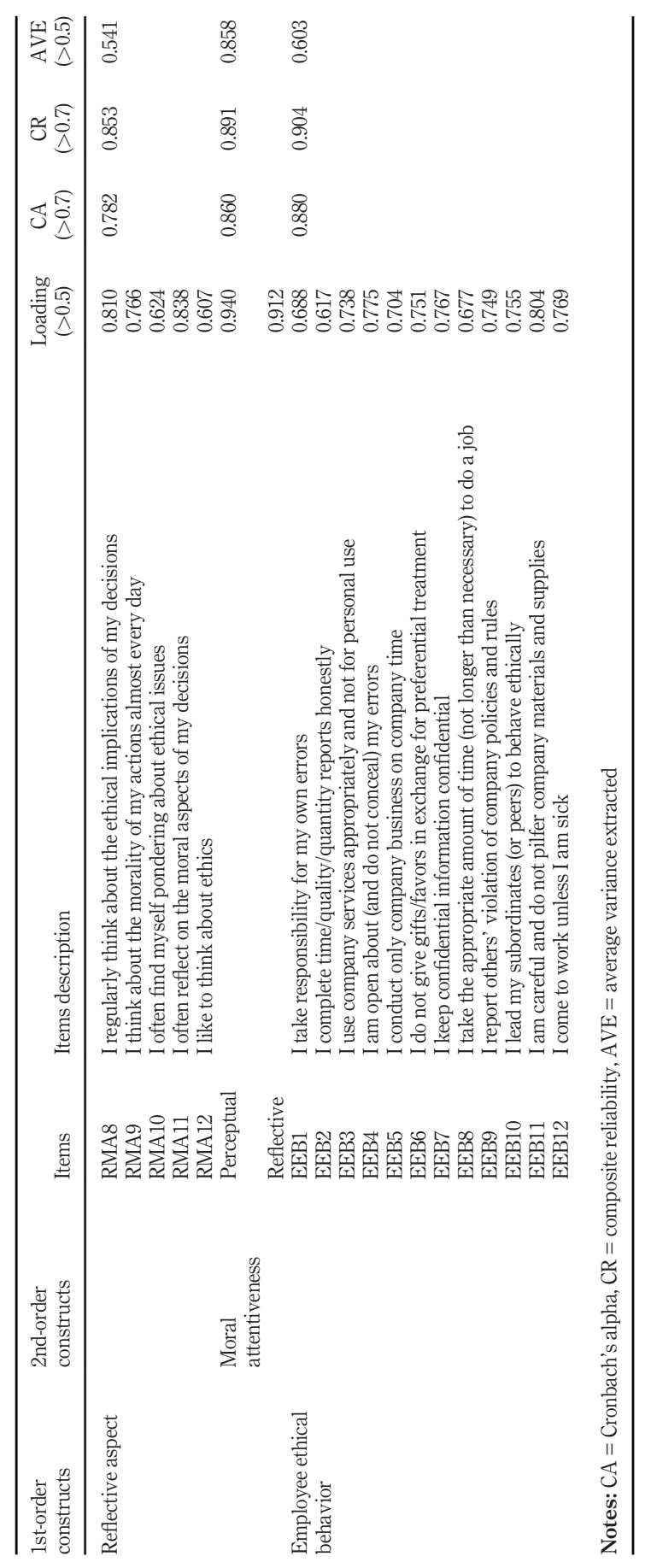

Leveraging ethical behavior

Table 1. 
to build the moral attentiveness second-order construct, such that higher scores indicated greater employee moral attentiveness.

3.2.3 Employee ethical behavior. To assess this first-order variable, 12-item scale were slightly adapted from previous studies (Ferrell and Weaver, 1978; Newstrom and Ruch, 1975). In particular, employees were asked to assess their agreement regarding whether they exhibited 12 behaviors that reflect universal moral principles that lead to human growth and encourage the effective functioning of the organization. An example item was "I conduct only company business on company time." Higher scores on this scale indicated a stronger ethical behavior of employees.

3.2.4 Control variables. Age, gender, job experience and education served as control variables for their potential relation to ethical behavior (Craft, 2013; O'Fallon and Butterfield, 2005). Age, education and job experience were measured with an ordinal scale anchored between 1 (younger, lower education, less job experience) and 5 (older, higher education, more job experience). Gender was, dichotomized ( $0=$ male, $1=$ female). Finally, SDB was captured because respondents had to indicate their own ethical behavior and thus to be able to control for the potential bias it could involve. Three items from Fischer and Fick (1993) were used, with some of them negatively worded, so that items were recoded them to indicate with higher scores a stronger SDB. One of these items had a loading far above the 0.7 thresholds ("I have never been annoyed when people expressed ideas very different from my own," item loading $=0.97$ ). The other two remaining items had loadings far above the acceptable value of 0.55 (Falk and Miller, 1992) ("There have been occasions when I took advantage of someone," item loading of 0.58; "I sometimes try to get even rather than forgive and forget," item loading of 0.69). The scale showed values for Cronbach's alpha (CA $=0.71)$ and composite reliability ( $\mathrm{CR}=0.74$ ) higher than 0.7 and an average variance extracted (AVE) value of 0.51 (higher than 0.5 , as recommended, Hair et al., 2017), which supports the internal consistency and convergent validity of this variable (Hair et al., 2017).

\subsection{Common method variance}

In addition to the ex-ante procedural remedies described above, a post hoc test was conducted to evaluate whether CMV could have biased the findings. Despite CMV not being able to inflate the interaction terms findings (Podsakoff et al., 2012), which are the central objective in this study. Still, the assessment of CMV is important to check whether this issue could have biased the findings. Harman's (1976) single-factor test revealed no problems of this type. The purpose of this test is to run an exploratory factor analysis to know whether a single factor emerges to explain the majority of the covariance among all the items used in this study (Afthanorhan et al., 2021). Because this test showed seven factors with eigenvalues greater than 1 to account for $68 \%$ of the total variance, it reveals no principal factor - the variance of the first factor accounts for only $32 \%$ of the total variance, which is less than 50\%. Thus, CMV is likely not to be a concern in this study (Podsakoff et al., 2003).

\section{Data analysis and results}

To verify the proposed hypotheses, the Smart PLS 3.2.6 was used (Ringle et al., 2015). This is a robust statistical procedure (Henseler et al., 2009) that supports the inclusion of first and second-order constructs in the same analysis (Hair et al., 2017), which suits the study requirements. To test the significance of path coefficients, 5,000 subsamples were used to generate bootstrap $t$-statistics with $n-1$ degrees of freedom (where $n$ is the number of subsamples). 


\subsection{Measurement model}

The measurement model covers several aspects (i.e. item reliability, internal consistency reliability, convergent validity and discriminant validity), which were all assessed (Tables 1 and 2). In terms of individual item reliability, most items exceeded the recommended 0.707 level (Hair et al., 2017; Table 2) or were above the acceptable 0.6 thresholds (Hulland, 1999; Table 1). CA and CR values for the variables ranged from 0.707 to 0.883 and 0.818 to 0.915 , respectively, indicating values far above the threshold of 0.7 , and therefore confirming internal consistency for all the variables in the study, both for first and second-order variables (Hair et al., 2017, Table 1). For the convergent validity for the variables of this study was also confirmed given that the AVE values for all constructs exceeded the 0.5 in all the cases (AVE values ranged from 0.531 to 0.858 , see Table 1) (Hair et al., 2017). Finally, discriminant validity was also confirmed by Fornell-Larcker and heterotrait-monotrait ratio (HTMT) inference criteria. Based on the results, the square roots of AVE for each variable were greater than the correlation of each variable with the others, and HTMT values were significantly different from 1 (Fornell and Larcker, 1981; Hair et al., 2017; see Table 2).

\subsection{Hypotheses testing}

To rule out alternative explanations of the findings and to reduce error (Becker, 2005). Therefore, personal attributes of individual characteristics were controlled by (age, gender, education, job experience). Therefore, none of these variables used as control variables (i.e. age, gender, education, job experience, SDB) showed a significant effect on employee ethical behavior (Figure 2). Unlike the prior studies, for example, Reiss and Mitra's (1998) locus of control (i.e. gender and years of job experience) were found to have some effect on whether an individual considered a certain behavior acceptable or unacceptable. Also, Holtbrügge et al. (2015) found that gender, age significantly influence the ethical behavior of employees. On the other hand, $\mathrm{Fu}$ (2014) displayed that the age of the employee had a significant negative impact on ethical behavior. This is clearly due to the cultural difference, the cultural characteristics of this society (Malaysia) (high power distance, short-term orientation, high collectivism) (Hofstede Center, 1967-2010) might affect employees' reactions to the context (Treviño et al., 2006; Fu et al., 2007). Regarding SDB, it showed a non-significant link to employee ethical behavior, either ( $\beta=0.06 \mathrm{~ns}$, Figure 2$)$, thus indicating that this bias is unlikely to have affected the findings.

Regarding hypotheses testing, Tables 3 and 4 and Figures 2 and 3 present the findings related to the hypotheses. According to the partial least squares analysis, no multicollinearity concerns were found, as variance inflation factor values ranged from 1.073 to 1.471, far lower than the 5.0 cut-off (Hair et al., 2017). In support of $H 1$, the findings revealed that organizational justice is positively related to employee ethical behavior ( $\beta=$ $0.385, p<0.001$, Table 3, Figure 2). In testing $H 2$, findings also allowed that to accept this hypothesis, as moral attentiveness was positively related to employee ethical behavior, as had predicted in line with the previous literature ( $\beta=0.197, p<0.001$, Table 3, Figure 2).

Finally, to test the moderation prediction in $H 3$, the standardized scores of the variables, to minimize multicollinearity (Low and Mohr, 2001). Organizational justice and employee moral attentiveness were entered in Step 1, then their interaction term in Step 2. According to the results in Table 3 , there is a significant "organizational justice $\times$ moral attentiveness" interaction effect ( $\beta=0.131, p<0.01$, Table 3, Figure 2), in line with the predictions. Nevertheless, to interpret this interaction, Dawson's (2014) suggestions was followed and plotted high versus low employee moral attentiveness regression lines $(+1$ and -1 standard deviation from the mean). This step indicates that the positive relationship between 
IJOES

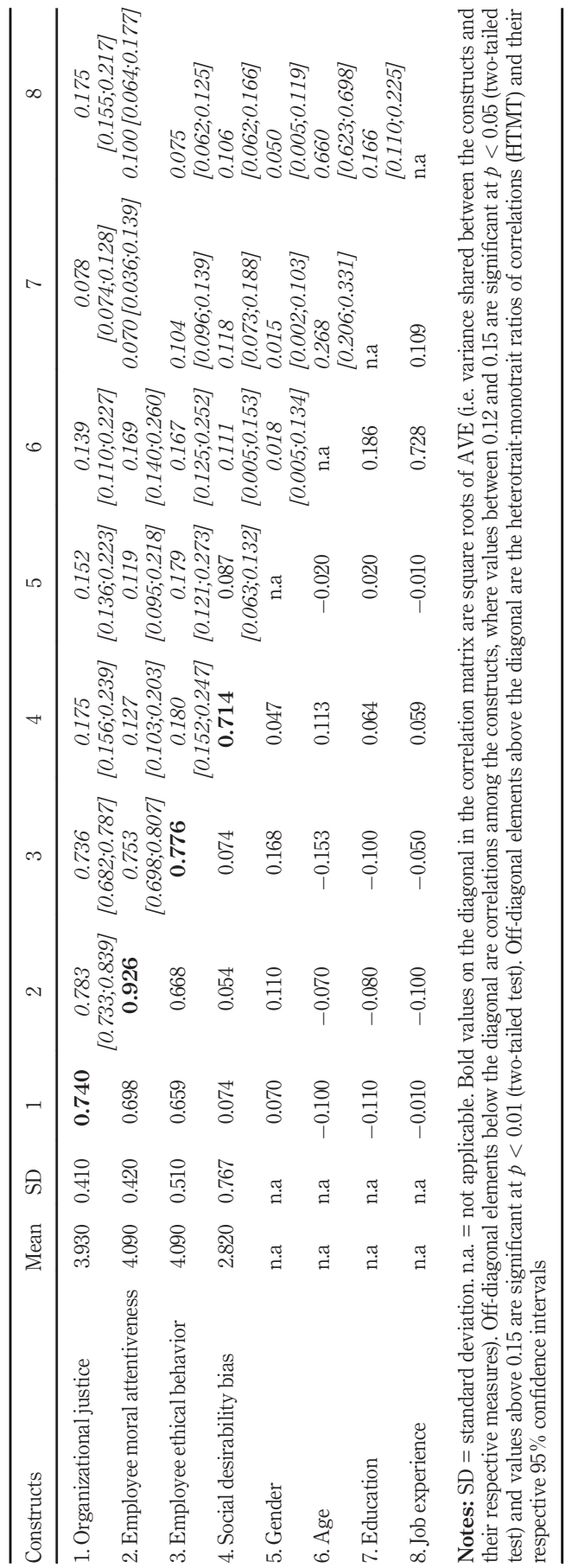

Table 2.

Descriptive statistics, correlation matrix and discriminant validity (square root of the AVE in bold and HTMT in italics)

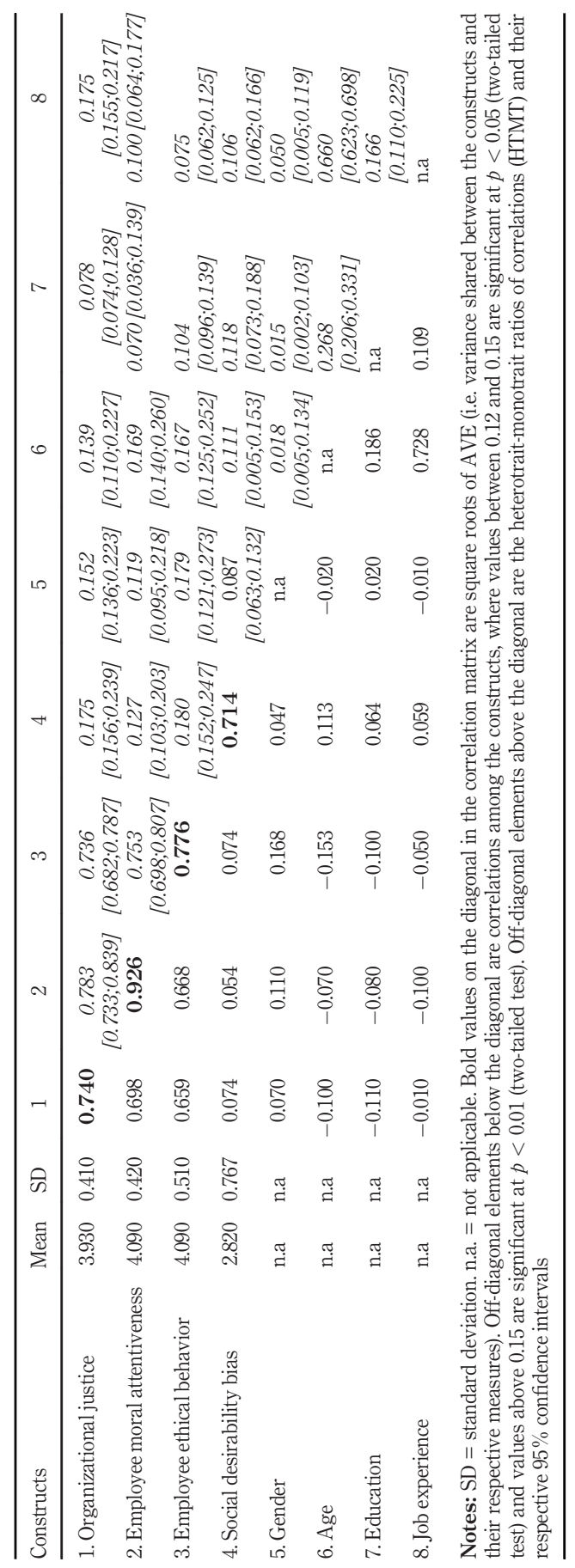




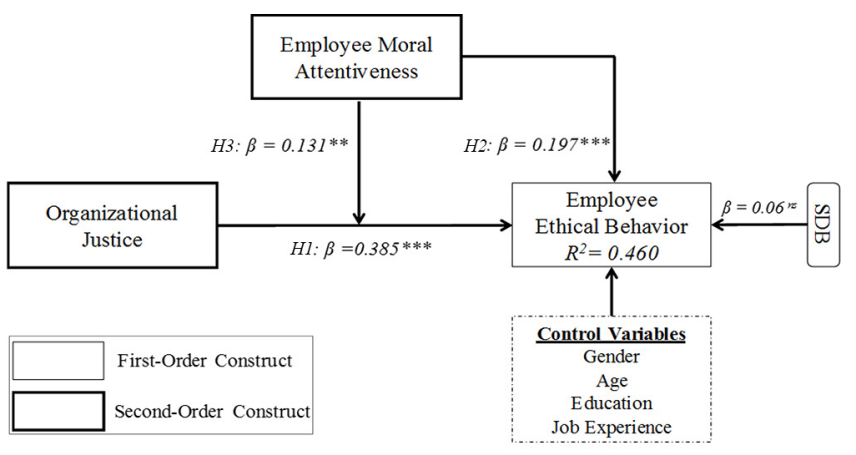

Notes: $\mathrm{SDB}=$ social desirability bias; $* * * p<0.001, * * p<0.01$; $\mathrm{ns}=$ not significant. Demographic variables had no significant effects on employee ethical behavior: gender $(\beta=0.03$, ns), age, $(\beta=-0.08, \mathrm{~ns})$, education $(\beta=0.04, \mathrm{~ns})$ and job experience $(\beta=-0.04, \mathrm{~ns})$
Leveraging ethical behavior
Hypothesis testing direct and interaction effects Relationship
Bias and corrected bootstrap 95\% confidence interval

\begin{tabular}{|c|c|c|c|c|c|}
\hline$H 1$ & $\mathrm{OJ} \rightarrow \mathrm{EEB}$ & $0.385^{* * * * *}$ & 0.061 & {$[0.275$} & $0.475]$ \\
\hline H2 & $\mathrm{MA} \rightarrow \mathrm{EEB}$ & 0.197 **** & 0.067 & {$[0.075$} & $0.293]$ \\
\hline H3 & $\mathrm{OJ} \times \mathrm{MA} \rightarrow \mathrm{EEB}$ & $0.131^{* * *}$ & 0.052 & 0.041 & $0.203]$ \\
\hline
\end{tabular}

Figure 2.

Research model: hypotheses testing

Notes: $\mathrm{OJ}=$ organizational justice, $\mathrm{EEB}=$ employee ethical behavior; $\mathrm{MA}=$ moral attentiveness. SD, direct and interaction standard deviation, $* * * p<0.001 ; * * p<0.01$

\begin{tabular}{|c|c|c|c|c|c|}
\hline Independent-dependent variables & $\begin{array}{l}\text { Direct } \\
\text { model }\end{array}$ & $\begin{array}{l}\text { Variance expl } \\
\text { Moderated } \\
\text { model }\end{array}$ & $\begin{array}{l}\text { lained } \\
\Delta \text { Variance } \\
\text { explained }\end{array}$ & $\begin{array}{l}\text { Size of the } \\
\text { moderation effect } \\
\left(f^{2}\right)\end{array}$ & Table 4. \\
\hline $\begin{array}{l}\text { With OJ and MA as independent variables } \rightarrow \mathrm{EEB} \\
\text { With the interaction "OJ X MA" added } \rightarrow \mathrm{EEB}\end{array}$ & 0.405 & 0.460 & 0.055 & 0.10 (small-moderate) & $\begin{array}{l}\text { moderation model: } \\
\text { change in variance }\end{array}$ \\
\hline \multicolumn{5}{|c|}{$\begin{array}{l}\text { Notes: } \mathrm{OJ}=\text { organizational justice, } \mathrm{EEB}=\text { employee ethical behavior; } \mathrm{MA}=\text { moral attentiveness. } f^{2}=\left(R^{2}\right. \\
\left.\text { included }-R^{2} \text { excluded }\right) /\left(1-R^{2} \text { included); effect sizes of } f^{2} \geq 0.02, \geq 0.15 \text {, and } \geq 0.35 \text { are small, moderate and }\right. \\
\text { large, respectively (Cohen, } 1988)\end{array}$} & $\begin{array}{r}\text { explained and } \\
\text { moderation effect } \\
\text { sizes }\end{array}$ \\
\hline
\end{tabular}

organizational justice and employee ethical behavior is stronger (slope is more pronounced) when employee moral attentiveness is high rather than low (Figure 3). In clear support of $H 3$, the relationship between organizational justice and employee ethical behavior is intensified at higher levels of employee moral attentiveness, so moral attentiveness has a strengthening "small-to-moderate" effect in the positive relationship between organizational justice and employee ethical behavior $\left(f^{2}=0.10\right.$, Cohen, 1988, Table 4). While according to 


\section{IJOES}

the plot graphed in Figure 3, organizational justice perceptions have a positive impact on employee ethical behavior (H1, Table 3, Figure 2) even among low morally attentive employees (Figure 3), moral attentiveness improves employee ethical behavior itself ( $H 2$, Table 3, Figure 2) and could help to make organizational justice to sway employees to behave up to the highest moral excellence levels possible, as predicted in H3 (Figure 3).

In terms of explanatory power, the model explains a $\left(R^{2}=46 \%\right)$ of the total variance of employee ethical behavior (Figure 2), which according to Hair et al. (2017), implies a moderate effect of this model on this variable. The Stone-Geisser blindfolding sample reuse technique also reveals a Q-square value greater than 0 , so the model effectively predicts employee ethical behavior $\left(Q^{2}=0.261\right)$ (Hair et al., 2017). Finally, in terms of overall goodness-of-fit, the standardized root means square residual (SRMR) index offers a value of 0.041, which is far below the 0.08 cut-off (Henseler, 2017). Also, the SRMR's 95\% bootstrap quantile is 0.054 , and thus is higher than the SRMR value, which indicates that the model has a good fit (Hair et al., 2017). Finally, the discrepancy indexes unweighted least squares discrepancy (dULS) andgeodesic discrepancy $(\mathrm{dG})$ are also under the bootstrap-based $95 \%$ percentile (dULS $=1.421<$ HI 95 of dULS $=2.521 ; \mathrm{dG}=0.562<\mathrm{HI} 95$ of $\mathrm{dG}=0.989$ ) (Hair et al., 2017). Overall, the discrepancy between the empirical and the model-implied correlation matrix is non-significant, which suggests no reasons to reject the model, or in other words, that the model tested is likely to be true (Henseler, 2017).

\section{Discussion and conclusion}

\subsection{General discussion}

This study aimed to examine the direct effect of organizational justice and moral attentiveness toward employee ethical behavior. Significantly, we also examined the moderating role of moral attentiveness on the relationships among organizational justice and the ethical behavior of employees. Therefore, the findings of this study indicated that organizational justice and moral attentiveness were significantly related to employee ethical behavior. So, both variables, as discovered, have a beneficial impact on employee ethical behavior. Importantly, the relationship between organizational justice and employee ethical behavior is stronger when the employee embraces high moral attentiveness than low. Thus, indicating that employees' level of moral attentiveness can augment the favorable impact of organizational justice on employee ethical behavior. Therefore, this study brings to important conclusions: First, by contributing to make employees perceive that justice is lived up in all the internal aspects and intricacies of the organization (e.g. outcomes,

Figure 3.

The "Organizational Justice $\times$ Moral Attentiveness" interaction on ethical behavior

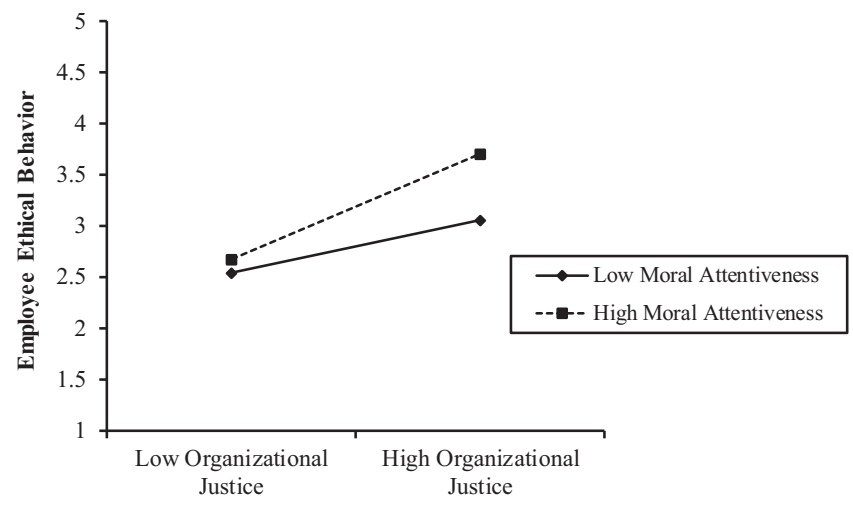


procedures, interpersonal treatment, information), the organization can enhance the levels of ethical behavior in the workplace. Second, in obtaining high levels of ethical behavior among employees, general managers should be conscious that moral attentiveness of employees is critical: not only does this quasi-personality trait drives employees to a higher level of ethical behavior but also would make more effective any effort made by general managers directed to make employees perceive that justice is actually lived in their organization.

\subsection{Theoretical contributions}

This study contributes to ethical behavior literature in various ways. First, while organizational justice has been largely studied for its important role in influencing a large variety of outcomes (Colquitt and Greenberg, 2003), its impact on employee ethical behavior has been less studied (McCain et al., 2010; Treviño et al., 2014). Also, when studying this relationship, researchers have focused principally on investigating the distinct, unique role of each dimension of organizational justice on the ethical behavior of employees, especially the role of distributive, procedural or interpersonal justice. Thus, the current study is one of the few that investigates and shows how organizational justice, as a whole construct integrated by its different dimensions (i.e. distributive, procedural, interpersonal and informational), is able to enhance the ethical behavior of employees.

Second, moral attentiveness is a relatively new concept in the ethics literature (van Gils et al., 2015), so the findings advance the literature by showing its direct and moderating role to account for the variance of employee ethical behavior. Moral attentiveness is linked to screening and considering morality in the day-to-day experiences and is rooted in social cognitive theory grounds (Bandura, 1986) that predict that "where" individuals pay attention in their day-to-day activities has an important impact on their behavioral decisions (Fiske, 1993; Bandura, 1986); however, empirical research that notes a positive relationship of this variable to ethical behavior is still in its infancy. Thus, while it has been positively linked to aspects intimately associated with ethical decision making (i.e. moral imagination, moral awareness, Sturm, 2018), some other studies have failed to find any relationship of this variable to ethical behavior (van Gils et al., 2015). This study adds to this realm of research by showing that moral attentiveness can underlie enhanced ethical behavior among employees.

Besides the demonstration of this direct effect of moral attentiveness on employee ethical behavior, one of the most important contributions of this study is the identification of moral attentiveness as a boundary condition for the organizational justice-ethical behavior relationship. While more consideration in empirical research to the cognitive processes that precede moral behavior has been called for (Zhu et al., 2016), only a few studies have echoed this call (Sturm, 2018; van Gils et al., 2015), and this is one of them, thus adding to the identification of moral attentiveness as a concept that is vital in explaining the transition of external moral stimuli into moral behavior (Hannah et al., 2011; Tenbrunsel and SmithCrowe, 2008). In addition, this study adds to the current literature by adding evidence concerning the individual-situation interactionist perspective that suggests that ethical behavior can be better explained by the interplay between organizational and individual variables (O'Keefe et al., 2019; Treviño, 1986; Treviño et al., 2006). Such a finding faithfully reflects the foundational theoretical perspective (i.e. social cognitive theory) in which the concept of moral attentiveness is rooted upon (Bandura, 1986; Fiske, 1993) by showing that an individual's behavior is principally a function of the individual and its personality (e.g. moral attentiveness) and the external stimuli (e.g. organizational justice). 
Overall, this study brings organizational justice, moral attentiveness and employee ethical behavior together for the first time in the literature. Moreover, the current study focuses on a non-Western context like Malaysia, which is of high relevance, given that the current organizational justice literature over-focuses on Western contexts. This is also important because Malaysia is a multi-racial society with Malay, Chinese, Indian and other ethnicities, which expresses important differences in terms of beliefs, religion, ideology and identity (Weintraub, 2011), so this study offers important evidence of the generalizability in other cultures of the positive influence of organizational justice perceptions on employee ethical behavior and the positive impact of moral attentiveness on employee ethical behavior - both in direct terms and by strengthening the expected positive impact of organizational justice on employee ethical behavior. Finally, by confirming the reliability and validity of Reynolds' (2008) moral attentiveness scale in Malaysia, this study helps to the robustness of the theory that underlies the moral attentiveness phenomenon and its two critical dimensions (i.e. perceptual, reflective), as this concept, to date, has been mostly studied on Western-cultural contexts (USA, Wurthmann, 2013; Reynolds, 2008; Whitaker and Godwin, 2013; The Netherlands, van Gils et al., 2015; UK, Dawson, 2018). Only Dong and $\mathrm{Ni}$ (2016) have used this concept in non-Western geography, and in their study, one item of the original Reynolds' (2008) scale had to be dropped. This study is one of fewer that applies this scale in a non-Western, multicultural context (i.e. Malaysia), and confirms scale dimensionality (perceptual and reflective dimensions) for all the original Reynold's (2008) 12 items (Table 1).

\subsection{Practical implications}

Findings of this study send a clear signal to managers that "failing to ensure that their employees perceive organizational justice" may undermine every effort made by them to improve their organizations' ethical quality. Considering that organizational justice has emerged as a key activator of employee ethical conduct, managers need to be aware that any efforts aimed at enhancing the sense of justice in the results obtained, procedures followed, supervisor-employee interactions developed and knowledge obtained are essential to enhancing their organizational moral conduct. In this sense, general managers could devote their efforts to designing good internal communication systems and open different communication channels to allow organizational members to become rapidly informed about decisions made at any level of the organization and especially about things that are most relevant to their interests. In addition, General managers should not disregard the value of training programs aimed at informing each supervisor in the organization about the significance of and how to provide appropriate rationales for their actions to their members of the team (Al Halbusi and Tehseen, 2018). Also, these training programs could involve strategies on how to treat their team members with dignity and respect. Managing how orders are given or how to tell employees they underperformed or made an error in doing their job tasks could improve the level of organizational justice (interpersonal justice) that employees perceive.

Importantly, the findings emphasize the role of moral attentiveness in improving the ethical behavior of employees both directly and by strengthening the effectiveness of organizational justice to impact such a behavior positively. So, given the advantages of moral attentiveness in terms of improving employee ethical conduct, businesses should make every effort to hire and choose people who meet this requirement because it is not easy to spot this personality trait. Human Resource Managers may assess candidates' moral attentiveness using a range of methods such as group debate, an in-basket exercise, organized interviews and business games that concentrate on specific ethical 
concerns. Furthermore, given that this trait can be trained, supervisors may commit energy and resources to implement training programs oriented to teach behavioral patterns on how to solve various ethical issues, so employees' attentiveness levels become increased to any moral cue that reminds them of these issues. Finally, personal or professional experiences resulting from interactions with role models could result in enhanced levels of moral attentiveness (Reynolds, 2008). As such, managers should do their utmost to become role models of ethical behavior as the virtuousness showed to others could make employees gather knowledge on how to perform successfully in moral terms and thus become motivated enough to flourish in moral terms, which should increase their attentiveness to the opportunities that exist in the environment to fulfill such a commendable goal (Al Halbusi and Amir Hammad Hamid, 2018; Dawson, 2018; Salehi et al., 2020a, 2020b).

\subsection{Limitations and future research directions}

This study is not without limitations. The first limitation refers to our cross-sectional data design, which makes it difficult to provide final conclusions about causality. Thus, important elements were recommended for future researchers interested in advancing our research model that finds creative formulas to designing experimental or longitudinal designs that help reinforce the causality findings of this study.

The second limitation of this study lies in the data. In this study, our data came from a single source, and CMV could have affected our findings. However, because our principal research question had to do with the "moral attentiveness $\times$ organizational justice" interaction, CMV is less than likely to affect our findings (Podsakoff et al., 2012). Also, the recommendations of Podsakoff et al.'s (2012) were faithfully followed to avoid this bias by principally conducting two survey waves in the data collection phase. Self-reported data even may be more advantageous for measuring ethical behavior than other-rated measures because employees are primarily of their own behaviors. Nonetheless, further studies aware could help extend our findings by collecting judgments from other sources concerning variables such as organizational justice.

Finally, this research did not take other factors into account in explaining ethical behavior. The ethical issue is a highly complex phenomenon that is affected by various variables at the individual and organizational level (Treviño et al., 2006; Craft, 2013; O'Keefe et al., 2019). As such, one must be cautious about the inferences made from the present study, which, to some extent, simplifies the ethical behavior by focusing on a few variables as determinants of ethical behavior in organizations. In this sense, moral awareness was not considered in this investigation; however, this concept is closely related to moral attentiveness (Reynolds, 2008). While moral attentiveness subconsciously promotes automatic processing and screening of information in the immediate environment before the person faces a specific issue, moral awareness is the recognition that a situation requires an ethical framework to be solved and involves a conscious process of comparing alternatives against moral standards once moral cues of a specific issue have been recognized (van Gils et al., 2015). Thus, moral awareness is likely to be required for an individual before this individual takes an ethical decision (Jones, 1991; Butterfield et al., 2000) and could interact with moral attentiveness to enhance the ethical behavior of employees.

It would also be useful to investigate the role of moral attentiveness in ensuring that employees believe that justice exists in their workplaces. The moral tone of a business is determined by the CEO or general manager (van Gils et al., 2015), with significant trickledown ethics effects (Schaubroeck et al., 2012; O'Keefe et al., 2019), including the shaping
Leveraging ethical behavior 
of the organizational justice perceptions of employees (Ko et al., 2018). Nevertheless, the effect of these managers' good character on employees' judgments of organizational justice may be dependent on their level of moral awareness. It would be interesting to investigate the impact of moral attentiveness in situations where CEOs develop behaviors that benefit the organization and its members while also displaying unethical beliefs toward other stakeholders. Since morally attentive employees prefer moral behavior and can recall ethical prototypes for dealing with specific moral-content situations (Sturm, 2018), the presence of unethical leaders in the upper echelons whose behavior is inconsistent with their moral view (van Gils et al., 2015) may cause these employees to be highly skeptical about whether justice is actually lived in the functioning of their organization. Overall, future researchers interested in furthering the findings of this study will have a plethora of options.

\section{References}

Adams, J.S. (1963), "Towards an understanding of inequity", The Journal of Abnormal and Social Psychology, Vol. 67 No. 5, pp. 422-436.

Afthanorhan, A., Awang, Z., Abd Majid, N., Foziah, H., Ismail, I., Al Halbusi, H. and Tehseen, S. (2021), "Gain more insight from common latent factor in structural equation modeling", Journal of Physics: Conference Series, IOP Publishing, Vol. 1793 No. 1, p. 12030.

Al Halbusi, H. and Amir Hammad Hamid, F. (2018), "Antecedents influence turnover intention: theory extension”, Journal of Organizational Behavior Research, Vol. 3 No. 2, pp. 287-304.

Al Halbusi, H. and Tehseen, S. (2017), "Corporate social responsibility (CSR): a literature review", Malaysian Journal of Business and Economics (MJBE), Vol. 4 No. 2, pp. 30-48.

Al Halbusi, H. and Tehseen, S. (2018), "Impact of ethical leadership on affective commitment through mediating impact of ethical climate: a conceptual study", Durreesamin Journal, Vol. 4 No. 2, pp. 1-14.

Al Halbusi, H., Tehseen, S. and Ramayah, T. (2017), "The impact of organizational justice on the ethical leadership under the moderating influence of perceived support: a conceptual study", Malaysian Journal of Business and Economics, Vol. 4 No. 1, pp. 46-64.

Al Halbusi, H.A., Ismail, M.N. and Omar, S. (2019), "Examining the impact of ethical leadership on employees' ethical behavior: the role of organizational justice and employees' moral identity", Journal of Technology Management and Business, Vol. 6 No. 2, pp. 30-48.

Al Halbusi, H., Ruiz-Palomino, P., Jimenez-Estevez, P. and Gutiérrez-Broncano, S. (2021), "How upper/ middle managers' ethical leadership activates employee ethical behavior? The role of organizational justice perceptions among employees”, Front. Psychol, Vol. 12 No. 719, pp. 1-13.

Al Halbusi, H., Williams, K.A., Ramayah, T., Aldieri, L. and Vinci, C.P. (2020a), "Linking ethical leadership and ethical climate to employees' ethical behavior: the moderating role of personorganization fit", Personnel Review, Vol. 50 No. 1, pp. 159-185.

A1 Halbusi, H., Williams, K.A., Mansoor, H.O., Hassan, M.S. and Hamid, F.A.H. (2020b), "Examining the impact of ethical leadership and organizational justice on employees' ethical behavior: does person-organization fit play a role?", Ethics and Behavior, Vol. 30 No. 7, pp. 514-532.

Al Halbusi, H., Ruiz-Palomino, P., Morales-Sánchez, R. and Abdel Fattah, F.A.M. (2021a), "Managerial ethical leadership, ethical climate and employee ethical behavior: does moral attentiveness matter?", Ethics and Behavior, Vol. 31 No. 8, pp. 1-24.

Al Halbusi, H., Ismail, M.N. and Omar, S.B. (2021b), "Ethical leadership and employee ethical behaviour: exploring dual-mediation paths of ethical climate and organizational justice: 
empirical study on Iraqi organizations", International Journal of Business Governance and Ethics (Ethics), Vol. 15 No. 3, pp. 303-325.

Ambrose, M.L. and Schminke, M. (2009), "The role of overall justice judgments in organizational justice research: a test of mediation", Journal of Applied Psychology, Vol. 94 No. 2, pp. 491-500.

Leveraging ethical behavior

Bandura, A. (1986), Social Foundations of Thought and Action: A Social Cognitive Theory, PrenticeHall, Englewood Cliffs, NJ.

Bargh, J.A. (1989), "Conditional automaticity: varieties of automatic influence in social perception and cognition", in Uleman, J.S. and Bargh, J.A. (Eds), Unintended Thought: The Limits of Awareness, Intention, and Control of Basic Principles, Guilford, New York, NY, pp. 3-51.

Bargh, J.A. and Thein, R.D. (1985), "Individual construct accessibility, person memory, and the recalljudgment link: the case of information overload", Journal of Personality and Social Psychology, Vol. 49 No. 5, pp. 1129-1146.

Becker, J.-M., Klein, K. and Wetzels, M. (2012), "Hierarchical latent variable models in PLS-SEM: guidelines for using reflective-formative type models", Long Range Planning, Vol. 45 Nos 5/6, pp. 359-394.

Becker, T.E. (2005), "Potential problems in the statistical control of variables in organizational research: a qualitative analysis with recommendations", Organizational Research Methods, Vol. 8 No. 3, pp. 274-289.

Bies, R. and Moag, R. (1986), "Interactional justice: communication criteria of fairness", in Lewicki, R.J., Sheppard, B.H. and Bazerman, M.H. (Eds), Research on Negotiations in Organizations, JAI Press, Greenwich, pp. 43-55.

Blau, P. (1964), Power and Exchange in Social Life, John Wiley and Sons, New York, NY.

Brislin, R.W. (1980), "Cross-cultural research methods: strategies, problems, applications”, in Altman, I., Rapoport, A. and Wohlwill, J.F. (Eds), Human Behavior and Environment, Plenum Press, New York, NY, pp. 47-82.

Burney, L.L., Henle, C.A. and Widener, S.K. (2009), "A path model examining the relations among strategic performance measurement system characteristics, organizational justice, and extraand in-role performance", Accounting, Organizations and Society, Vol. 34 Nos 3/4, pp. 305-321.

Butterfield, K.D., Treviño, L.K. and Weaver, G.R. (2000), "Moral awareness in business organizations: influences of issue-related and social context factors”, Human Relations, Vol. 53 No. 7, pp. 981-1018.

Cho, E.H. and Tak, J.K. (2009), "Organizational justice and employee behaviors: the mediating roles of trust in CEO and supervisor", Korean Journal of Applied Statistics, Vol. 22 No. 3, pp. 463-477.

Cohen, J. (1988), Statistical Power Analysis for the Behavioral Sciences, 2nd ed., Routledge, New York, NY.

Colquitt, J.A. (2001), "On the dimensionality of organizational justice: a construct validation of a measure", Journal of Applied Psychology, Vol. 86 No. 3, pp. 386-400.

Colquitt, J.A. and Greenberg, J. (2003), "Organizational justice: a fair assessment of the state of the literature", in Greenberg, J. (Ed.), Organizational Behavior: The State of the Science, Lawrence Erlbaum Associates Publishers, Mahwah, NJ, pp. 165-210.

Colquitt, J.A., Conlon, D.E., Wesson, M.J., Porter, C.O. and Ng, K.Y. (2001), "Justice at the millennium: a meta-analytic review of 25 years of organizational justice research", Journal of Applied Psychology, Vol. 86 No. 3, pp. 425-445.

Colquitt, J.A., Scott, B.A. and LePine, J.A. (2007), "Trust, trustworthiness, and trust propensity: a metaanalytic test of their unique relationships with risk taking and job performance", Journal of Applied Psychology, Vol. 92 No. 4, pp. 909-927.

Craft, J.L. (2013), “A review of the empirical ethical decision-making literature: 2004-2011”, Journal of Business Ethics, Vol. 117 No. 2, pp. 221-259.

Cropanzano, R. and Greenberg, J. (1997), "Progress in organizational justice: tunneling through the maze", International Review of Industrial and Organizational Psychology, Vol. 12, pp. 317-372. 
Dawson, D. (2018), "Organizational virtue, moral attentiveness, and the perceived role of ethics and social responsibility in business: the case of UK HR practitioners", Journal of Business Ethics, Vol. 148 No. 4, pp. 765-781.

Dawson, J.F. (2014), "Moderation in management research: what, why, when, and how", Journal of Business and Psychology, Vol. 29 No. 1, pp. 1-19.

Demirtas, O. (2015), "Ethical leadership influence at organizations: evidence from the field", Journal of Business Ethics, Vol. 126 No. 2, pp. 273-284.

Dong, R. and Ni, S. (2016), "Psychometric properties of a Chinese version of the moral attentiveness scale", Ethics and Behavior, Vol. 28 No. 2, pp. 154-175, doi: 10.1080/10508422.2016.1274656.

El Akremi, A., Vandenberghe, C. and Camerman, J. (2010), "The role of justice and social exchange relationships in workplace deviance: test of a mediated model”, Human Relations, Vol. 63 No. 11, pp. 1687-1717.

Falk, R.F. and Miller, N.B. (1992), A Primer for Soft Modelling, University of Akron Press, Akron, OH.

Ferrell, O.C. and Weaver, K.M. (1978), "Ethical beliefs of marketing managers: what they say they believe and do, compared with their perceptions of peers and top management", Journal of Marketing, Vol. 42 No. 3, pp. 69-73.

Fischer, D.G. and Fick, C. (1993), "Measuring social desirability: short forms of the Marlowe-Crowne social desirability scale", Educational and Psychological Measurement, Vol. 53 No. 2, pp. 417-424.

Fiske, S.T. (1993), "Controlling other people: the impact of power on stereotyping", The American Psychologist, Vol. 48 No. 6, pp. 621-628.

Fiske, S.T. and Taylor, S.E. (1991), Social Cognition, 2nd ed., McGraw-Hill, New York, NY.

Fornell, C. and Larcker, D.F. (1981), "Evaluating structural equation models with unobservable variables and measurement error", Journal of Marketing Research, Vol. 18 No. 1, pp. 39-50.

$\mathrm{Fu}, \mathrm{W}$. (2014), "The impact of emotional intelligence, organizational commitment, and job satisfaction on ethical behavior of Chinese employees", Journal of Business Ethics, Vol. 122 No. 1, pp. 137-144.

Giessner, S. and Van Quaquebeke, N. (2010), "Using a relational model's perspective to understand normatively appropriate conduct in ethical leadership", Journal of Business Ethics, Vol. 95 No. S1, pp. 43-55.

Gouldner, A.W. (1960), "The norm of reciprocity: a preliminary statement", American Sociological Review, Vol. 25 No. 2, pp. 161-178.

Greenberg, J. (1990), “Organizational justice: yesterday, today, and tomorrow”, Journal of Management, Vol. 16 No. 2, pp. 399-432.

Greenberg, J. (2001), "Studying organizational justice cross-culturally: fundamental challenges", International Journal of Conflict Management, Vol. 12 No. 4, pp. 365-375.

Hair, J.F., Hult, G.T.M., Ringle, C. and Sarstedt, M. (2017), A Primer on Partial Least Squares Structural Equation Modeling (PLS-SEM), 2nd ed., Sage, Thousand Oaks.

Hannah, S.T., Avolio, B.J. and May, D.R. (2011), "Moral maturation and moral conation: a capacity approach to explaining moral thought and action", Academy of Management Review, Vol. 36 No. 4, pp. 663-685.

Harman, H.H. (1976), Modern Factor Analysis, 3rd ed., University of Chicago Press, Chicago, IL.

Henseler, J. (2017), "Bridging design and behavioral research with variance-based structural equation modeling", Journal of Advertising, Vol. 46 No. 1, pp. 178-192.

Henseler, J., Ringle, C.M. and Sinkovics, R.R. (2009), "The use of partial least squares path modelling in international marketing", in Sinkovics, R.R. and Ghauri, P.N. (Eds), New Challenges to International Marketing: Advances in International Marketing, Emerald JAI Press, Bingley.

Hofstede Center. (1967-2010), “Geert Hofstede cultural dimensions”, available at: https://geert-hofstede. $\mathrm{com} /$ (accessed 24 May 2019). 
Holtbrügge, D., Baron, A. and Friedmann, C.B. (2015), "Personal attributes, organizational conditions, and ethical attitudes: a social cognitive approach”, Business Ethics: A European Review, Vol. 24 No. 3, pp. 264-281.

Hulland, J. (1999), "Use of partial least squares (PLS) in strategic management research: a review of four recent studies", Strategic Management Journal, Vol. 20 No. 2, pp. 195-204.

Jones, T.M. (1991), "Ethical decision making by individuals in organizations: an issue-contingent model", The Academy of Management Review, Vol. 16 No. 2, pp. 366-395.

Karam, E.P., Hu, J., Davison, R.B., Juravich, M., Nahrgang, J.D., Humphrey, S.E. and Scott DeRue, D. (2019), 'Illuminating the 'face' of justice: a meta-analytic examination of leadership and organizational justice", Journal of Management Studies, Vol. 56 No. 1, pp. 134-171.

Ko, C., Ma, J., Bartnik, R., Haney, M.H. and Kang, M. (2018), "Ethical leadership: an integrative review and future research agenda", Ethics and Behavior, Vol. 28 No. 2, pp. 104-132.

Lin, X.W., Che, H.S. and Leung, K. (2009), "The role of leader morality in the interaction effect of procedural justice and outcome favorability", Journal of Applied Social Psychology, Vol. 39 No. 7 , pp. 1536-1561.

Lind, E.A. (2001), "Fairness heuristic theory: justice judgments as pivotal cognitions in organizational relations", in Greenberg, J. and Cropanzano, R. (Eds), Advances in Organization Justice, Stanford University Press, Standford, CA, pp. 56-88.

Lind, E.A. and Tyler, T.R. (1988), The Social Psychology of Procedural Justice, Plenum, New York, NY.

Low, G.S. and Mohr, J.J. (2001), "Factors affecting the use of information in the evaluation of marketing communications productivity", Journal of the Academy of Marketing Science, Vol. 29 No. 1, pp. 70-88.

McCain, S.-L.C., Tsai, H. and Bellino, N. (2010), “Organizational justice, employees' ethical behavior, and job satisfaction in the casino industry", International Journal of Contemporary Hospitality Management, Vol. 22 No. 7, pp. 992-1009.

Mayer, D.M., Kuenzi, M., Greenbaum, R., Bardes, M. and Salvador, R.B. (2009), "How low does ethical leadership flow? Test of a trickle-down model", Organizational Behavior and Human Decision Processes, Vol. 108 No. 1, pp. 1-13.

Mitchell, M.S., Reynolds, S.J. and Treviño, L.K. (2017), "The study of behavioral ethics within organizations", Personnel Psychology, Vol. 70 No. 2, pp. 313-314.

Moardi, M., Salehi, M. and Marandi, Z. (2016), "The role of tolerance of ambiguity on ethical decisionmaking students: a comparative study between accounting and management students", Humanomics, Vol. 32 No. 3, pp. 300-327.

Newstrom, J.W. and Ruch, W.A. (1975), "Ethics of management and management of ethics", $M S U$ Business Topics, Vol. 23 No. 1, pp. 29-37.

O'Fallon, M.J. and Butterfield, K.D. (2005), "A review of the empirical ethical decision-making literature: 1996-2003”, Journal of Business Ethics, Vol. 59 No. 4, pp. 375-413.

O'Keefe, D.F., Howell, G.T. and Squires, E.C. (2019), "Ethical leadership begets ethical leadership: exploring situational moderators of the trickle-down effect", Ethics and Behavior, Vol. 30 No. 8 , pp. 581-600, doi: 10.1080/10508422.2019.1649676.

Oshio, T. and Kobayashi, M. (2009), "Income inequality, area-level poverty, perceived aversion to inequality, and self-rated health in Japan”, Social Science and Medicine, Vol. 69 No. 3, pp. 317-326.

Podsakoff, P.M., MacKenzie, S.B., Lee, J.Y. and Podsakoff, N.P. (2003), "Common method biases in behavioral research: a critical review of the literature and recommended remedies", Journal of Applied Psychology, Vol. 88 No. 5, p. 879.

Podsakoff, P.M., MacKenzie, S.B. and Podsakoff, N.P. (2012), "Sources of method bias in social science research and recommendations on how to control it", Annual Review of Psychology, Vol. 63 No. 1, pp. 539-569. 
Pratono, A.H. (2019), "Linking religiosity to citizenship behaviour under materialism attitude: empirical evidence from Indonesia", International Journal of Ethics and Systems, Vol. 35 No. 1, pp. 75-89, doi: 10.1108/IJOES-07-2018-0104.

Reiss, M.C. and Mitra, K. (1998), "The effects of individual difference factors on the acceptability of ethical and unethical workplace behaviors", Journal of Business Ethics, Vol. 17 No. 14, pp. 1581-1593.

Reynolds, S.J. (2006), "Moral awareness and ethical predispositions: investigating the role of individual differences in the recognition of moral issues", Journal of Applied Psychology, Vol. 91 No. 1, pp. 233-243.

Reynolds, S.J. (2008), “Moral attentiveness: who pays attention to the moral aspects of life?", Journal of Applied Psychology, Vol. 93 No. 5, pp. 1027-1041.

Reynolds, S.J. and Ceranic, T.L. (2009), "On the causes and conditions of moral behavior; why is this all we know?", in De Cremer, D. (Ed.), Psychological Perspectives on Ethical Behavior and Decision Making, Information Age Publishing, Charlotte, NC, pp. 17-35.

Ringle, C.M., Wende, S. and Becker, J.-M. (2015), "SmartPLS 3. Bonningstedt: SmartPLS”, available at: www.smartpls.com (accessed 30 December 2019).

Roch, S.G., Shannon, C.E., Martin, J.J., Swiderski, D., Agosta, J.P. and Shanock, L.R. (2019), "Role of employee felt obligation and endorsement of the just world hypothesis: a social exchange theory investigation in an organizational justice context”, Journal of Applied Social Psychology, Vol. 49 No. 4, pp. 213-225.

Rounaghi, M.M. (2019), "Economic analysis of using green accounting and environmental accounting to identify environmental costs and sustainability indicators", International Journal of Ethics and Systems, Vol. 35 No. 4, pp. 504-512.

Salehi, M., Seyyed, F. and Farhangdoust, S. (2020a), "The impact of personal characteristics, quality of working life and psychological well-being on job burnout among Iranian external auditors", International Journal of Organization Theory and Behavior, Vol. 23 No. 3, pp. 189-205.

Salehi, M., Sima, H.H. and Fahimi, M.A. (2020b), "The relationship between organizational justice and auditors' professional skepticism with the moderating role of organizational commitment and identity", Current Psychology, pp. 1-13.

Sarstedt, M., Hair, J.F, Jr, Cheah, J.-H., Becker, J.-M. and Ringle, C.M. (2019), “How to specify, estimate, and validate higher-order constructs in PLS-SEM", Australasian Marketing Journal, Vol. 27 No. 3, pp. 197-211.

Schaubroeck, J., Hannah, S.T., Avolio, B.J. and Kozlowski, S.W.J. (2012), "Embedding ethical leadership within and across organization levels", The Academy o Management Journal, Vol. 55, pp. 5, 1053-1078.

Shah, N., Anwar, S. and Irani, Z. (2017), "The impact of organisational justice on ethical behaviour", International Journal of Business Innovation and Research, Vol. 12 No. 2, pp. 240-258.

Steensma, H. and Visser, E. (2007), "Procedural justice and supervisors' personal power bases: effects on employees' perceptions of performance appraisal sessions, commitment, and motivation", Journal of Collective Negotiations (Formerly Journal of Collective Negotiations in the Public Sector), Vol. 31 No. 2, pp. 101-118.

Sturm, R.E. (2018), "Decreasing unethical decisions: the role of morality-based individual differences", Journal of Business Ethics, Vol. 142 No. 1, pp. 37-57.

Tenbrunsel, A.E. and Smith-Crowe, K. (2008), "13 Ethical decision making: where we've been and where we're going”, Academy of Management Annals, Vol. 2 No. 1, pp. 545-607.

Treviño, L.K. (1986), "Ethical decision making in organizations: a person-situation interactionist model", Academy of Management Review, Vol. 11, pp. 601-617.

Treviño, L.K., Weaver, G.R. and Reynolds, S.J. (2006), "Behavioral ethics in organizations: a review", Journal of Management, Vol. 32 No. 6, pp. 951-990. 
Treviño, L.K., Den Nieuwenboer, N.A. and Kish-Gephart, J.J. (2014), “(Un) ethical behavior in organizations", Annual Review of Psychology, Vol. 65 No. 1, pp. 635-660.

van Gils, S., Van Quaquebeke, N., van Knippenberg, D., van Dijke, M. and De Cremer, D. (2015), "Ethical leadership and follower organizational deviance: the moderating role of follower moral attentiveness", The Leadership Quarterly, Vol. 26 No. 2, pp. 190-203.

Weintraub, A.N. (2011), Islam and Popular Culture in Indonesia and Malaysia, Routledge, London.

Whitaker, B.G. and Godwin, L.N. (2013), "The antecedents of moral imagination in the workplace: a social cognitive theory perspective", Journal of Business Ethics, Vol. 114 No. 1, pp. 61-73.

Wiernik, B.M., Ruger, H. and Ones, D.S. (2018), "Advancing expatriate research in public and private sectors", in Wiernik, B.M., Ruger, H. and Ones, D.S. (Eds), Managing Expatriates: Success Factors in Private and Public Domains, Barbara Budrich Publishers, Opladen.

Wurthmann, K. (2013), "A social cognitive perspective on the relationships between ethics education, moral attentiveness, and PRESOR”, Journal of Business Ethics, Vol. 114 No. 1, pp. 131-153.

Zhu, W., Treviño, L.K. and Zheng, X. (2016), "Ethical leaders and their followers: the transmission of moral identity and moral attentiveness", Business Ethics Quarterly, Vol. 26 No. 1, pp. 95-115.

\title{
Further reading
}

Al Halbusi, H., Ruiz-Palomino, P., Jimenez-Estevez, P. and Gutiérrez-Broncano, S. (2021c), "How upper/ Middle managers' ethical leadership activates employee ethical behavior? The role of organizational justice perceptions among employees", Frontiers in Psychology, Vol. 12.

\begin{abstract}
About the author
Hussam $\mathrm{Al}$ Halbusi holds a $\mathrm{PhD}$ in Management and Administration, currently working as Assistant Professor at Management Department, Ahmed Bin Mohammed Military College, Doha, Qatar. Hussam received his BSc degree with first-class honors from the University of Al Anbar in 2011. After completing his BSc in Business Management, he was awarded a master's degree in business policy from Fatih University Istanbul, Turkey 2015. He obtained his $\mathrm{PhD}$ from the Faculty of Business and Accountancy, University of Malaya, Malaysia, 2020. His interests lie in the areas of strategic management, business ethics, leadership, human resources management, organizational psychology, organizational sociology, innovation, entrepreneurship, SMEs, technology adaption and technology addiction. He has published numerous scientific journal articles and conference papers. $\mathrm{He}$ is a regular reviewer of numerous prestigious journals. During his career, he was engaged in more than 50 projects. Hussam Al Halbusi can be contacted at: hussam.mba@gmail.com
\end{abstract}

For instructions on how to order reprints of this article, please visit our website: www.emeraldgrouppublishing.com/licensing/reprints.htm Or contact us for further details: permissions@emeraldinsight.com 